\title{
45 THE TACIT DIMENSIONS OF COLLABORATIVE NETWORK TRAFFIC
}

\author{
Stephen Doak ${ }^{1}$, Dimitris Assimakopoulos ${ }^{2}$ \\ ${ }^{\prime}$ Forensic Scientist, Forensic Science Laboratory, Department of Justice, \\ Garda HQ, Phoenix Park, Dublin 8, IRELAND. \\ sdoak@fsl.gov.ie \\ ${ }^{2}$ Professor and Associate Dean of Research, Grenoble Ecole de Management, \\ Europole, 12 rue Pierre Semard, BP127, 38003 Grenoble, FRANCE. \\ dimitris.assimakopoulos@grenoble-em.com

\begin{abstract}
We have visualised informal internal and external networks of practicing forensic scientists and now set out to understand how such collaborative networks function. We propose that tacit knowledge acquired through relational mechanisms of social interaction is a major contributor to the functioning of collaborative networks. In our case study on a forensic science community, we examine empirically such tacit knowledge transfer flows at an inter-and intra-organisational collaborative level.
\end{abstract}

\section{INTRODUCTION}

Recent research has emphasized the need for a better understanding and characterisation of the basic principles and mechanisms of collaborative networks (Sofia Pereira \& Soares 2007). The actors within such networks rely very heavily on their network of relationships to find information and solve problems (Cross, Borgatti, \& Parker 2002). A unifying concept of the knowledge and learning gained through participant practice is its construction from 'relations among people engaged in an activity' (Osterlund \& Carlile 2005: p. 92). The benefit of these collaborative networks is more than just a conjoining - a synergy is achieved by pooling the thinking of multiple actors and organizations. We propose that the exchange of tacit knowledge (Herbig, Bussing, \& Ewert 2001; Polanyi 1966), mediated by the relational mechanisms of social actors interacting with each other, is a major contributor to the functioning of such collaborative networks.

As networks can by their nature be large, knowledge can become difficult to transfer within, especially where the discussion of ideas can be at the cutting edge and often require specialised expertise, which can be tacit (Bos et al. 2007). In looking at how collaborations function, we have visualised informal internal (Doak \& Assimakopoulos 2007b) and external (Doak \& Assimakopoulos 2006) networks of practicing forensic scientists and now set out to understand the mechanisms of how such collaborative networks function. We used social network analysis, to uncover

Doak, S., Assimakopoulos, D., 2007, in IFIP International Federation for Information Processing, Volume 243, Establishing the Foundation of Collaborative Networks; eds. Camarinha-Matos, L., Afsarmancsh, H., Novais, P., Analide, C.; (Boston: Springer), pp. 425-433. 
the structured relational connections shaping tacit knowledge flows between forensic scientists, both in their internal collaborative networks, and outside their homestead, in their inter-organisational collaborative networks. Our analysis took place at the micro-level, where we treated the forensic scientist and his/her network of advice relations as the unit of analysis indicative of tacit knowledge exchange.

Organisational learning can be seen as a function of relationships sitting on top of the structural properties within social networks. When viewing the relational aspect of social capital it is the nature of the relationships in the social structure that leads to certain benefits for the participant actors. The relational facet 'describes the kind of personal relationships people have developed with each other through a history of interactions (Nahapiet \& Ghoshal 1998: p. 244)'. However little is known about the kinds of relationships (in contrast to structural properties) that condition learning and knowledge flows within the networks (Borgatti \& Cross 2003). Trust, advice, respect, friendship and social norms are examples of such relational dimensions mediating dyadic knowledge exchanges. These relational factors matter most when the exchange involves tacit knowledge and indeed the exchange 'relies on the quality of a knowledge seeker's relationship with a knowledge source (Levin \& Cross 2004: p. 1481)'. Indeed Collins and Hitt, who have examined the 'link between relational capabilities (relational capital) and tacit knowledge transfer' call for 'firms to recognize the importance of inter-personal dynamics involved in the transfer of tacit knowledge' suggesting 'greater attention' is required to be given to the 'relational dimension of social capital (Collins \& Hitt 2006: p. 148)'.

Tacit knowledge within a collaborative network umbrella, is both exchanged between actors at a bounded local community of practice level (Lave \& Wenger 1991), and is transferred to actors who share a common interest externally outside of an organisation to the open environment through Networks of Practice (Wasko \& Faraj 2005). Networks of practice tie in directly with community of practices, where a community from one particular organisation becomes linked through common practices to communities in other organisations. These collaborative networks, where knowledge can flow, cut horizontally across vertically integrated local organisations (Brown \& Duguid 2000; Brown \& Duguid 2001). The relations among collaborative network members are significantly looser than those within a localised community of practice (Brown \& Duguid 2001), who commonly are geographically distributed (Wasko \& Faraj 2005). From a network of practice perspective, individuals have practice and knowledge in common but are mostly unknown to each other, whereas from a community of practice perspective, individuals are tightly knit into groups who know each other well and work together directly (van Baalen, Bloemhof-Ruwaard, \& van Heck 2006). Networks of practice show their strength in innovation when organizations that do not possess all required knowledge within their formal boundaries, must rely on linkages to outside organizations and individuals to acquire knowledge (Anand, Glick, \& Manz 2002).

Professions are a good example of collaborative networks, where similar practitioners, by virtue of their practice, are able to share professional knowledge through conferences, workshops, and web/email contact (Brown \& Duguid 2001). The sharing of knowledge is an important aspect of these technical professional communities (Bouty 2000). Such inter-organisational relations while implied in the literature, have rarely been examined empirically (Swan, Scarbrough, \& Robertson 2002; Wasko \& Faraj 2005). In our case study on a forensic science community, the 
Forensic Science Laboratory (FSL) Ireland, we examine empirically such tacit knowledge exchange, mediated within a relational environment at an inter-organisational collaborative level. Our micro-level case study provides an informative insight into the process of how tacit knowledge flows within and between collaborative networks, and how relations between social actors are an integral factor in the mechanisms of such networks.

\section{METHODS}

\subsection{Network visualisation of tacit knowledge transfer within/outside FSL}

FSL is the Republic of Ireland's forensic examination and analytical service for all criminal casework encompassing drugs, arson, DNA, toolmarks, paint and glass, explosives, firearm residue, fibre transfer and other trace-type cases. At the time this research was undertaken FSL employed over 43 forensic scientists at the one headquarters. Previous research, established the presence of four local collaborative communities of practice within FSL, comprising forensic scientist experts in the specialist areas of: Biology, DNA, Chemistry and Drugs (Doak \& Assimakopoulos 2007a; Doak \& Assimakopoulos 2007b). Using social network analysis [Pajek (Batagelj \& Mrvar 2005) \& Ucinet (Borgatti, Everett, \& Freeman 2002)] we had uncovered the advice relation mediating tacit knowledge transfer between forensic scientists within FSL, and here we visualise the tacit knowledge exchanges between forensic scientists in the inter-organisational collaborative networks peripheral to FSL.

Outside of their own inter-organisational collaborative networks, these forensic scientists gain access to knowledge of the tacit nature through their participation in networks of practice, professional associations and peer-attendee conferences. The forensic scientists at FSL are largely influenced by external forensic scientists who practice in fifty-three other forensic science laboratories, distributed over thirty-one European countries, under the umbrella organisation of the European Network of Forensic Science Institutes (ENFSI). ENFSI was established in 1995 for the purposes of sharing knowledge, exchanging experiences and coming to mutual agreements in the field of forensic science. Within ENFSI there are sixteen Expert Working Groups including DNA, digital evidence, fingerprints, scene of crime, drugs, fibres, paint $\&$ glass, and fires. These working groups comprise the backbone of this pan-european forensic science collaborative network in terms of the scientific knowledge and forensic science policy. We explore the digital evidence ENFSI working group through both through network analysis and participant observation, where the interactions of an FSL forensic scientist with the collaborative group has allowed a nascent digital evidence service to be set up back at FSL. We also view another collaborative group - the International Association of Blood Pattern Analysis (IABPA). 


\subsection{Personal insights of how Tacit Knowledge is exchanged within collaborative networks}

Over the period December 2006 to April 2007 a series of half hour-long, semistructured interviews were carried out with twenty-eight forensic scientists. The interviewees were all within the local inter-organisational collaborative network (FSL), who were selected through purposeful sampling, using knowledge giving capacities and network position criteria. Although the interviews entailed some degree of variation, the interview questions were selected around elements of tacit knowledge transfer/reciprocation covering the following topic areas: the learning of forensic science practice; the seeking/giving advice; establishment of how knowledge is gained/given; and the exploration of the concept of experience. The questions were developed to directly address the research proposition: that tacit knowledge, acquired through the relational mechanisms of social interaction, is a major contributor to the functioning of collaborative networks.

\section{RESULTS \& DISCUSSION}

\subsection{Collaborative Networks - a quantitative view}

Previously we mapped relational tacit knowledge flows amongst forensic scientists within/between the intra-organisational collaborative networks at FSL (Doak \& Assimakopoulos 2007b). We produced a snapshot of tacit knowledge exchange mediated by the advice relation over a three-day period (see Figure 1).

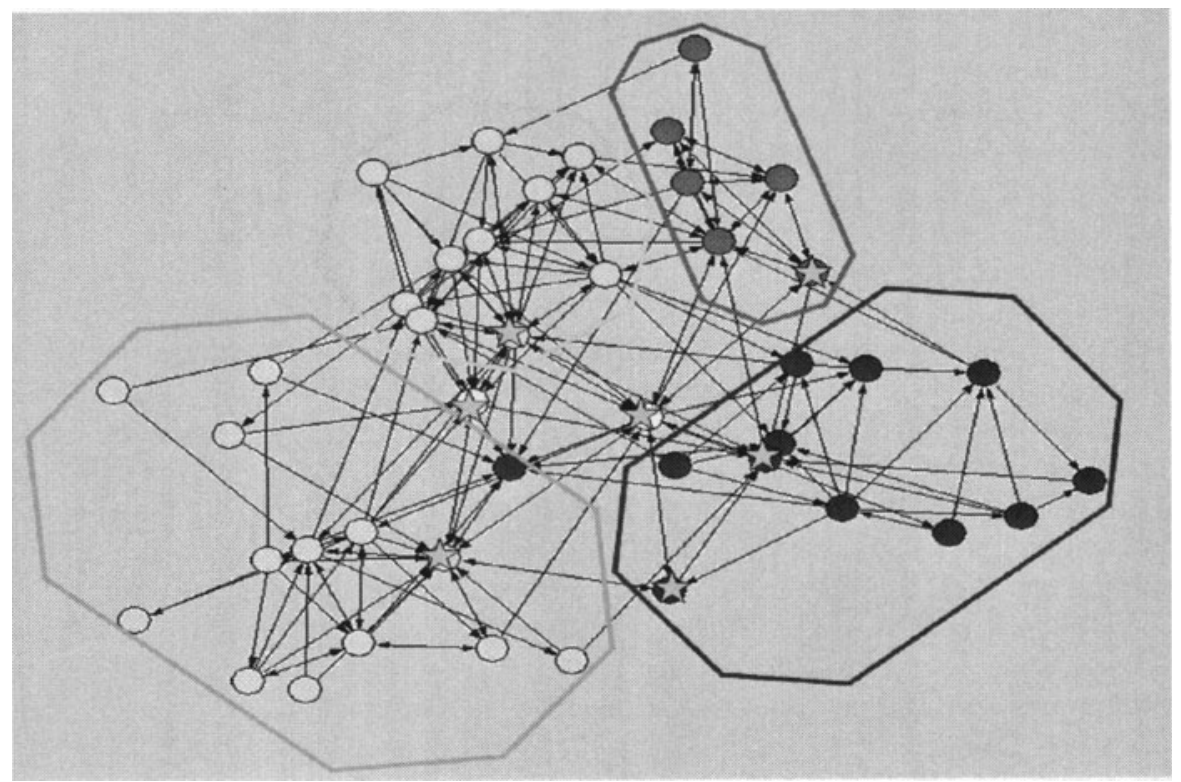

Figure 1. Network map of FSL, recording advices yielding tacit knowledge transfer between forensic scientists over a three-day period within/between four intra-organisational collaborative communities of practice networks. Biology (green), Chemistry (blue), DNA (red), Drugs (pink). 
Outside of their own local communities, we show quantitatively how forensic scientists gain access to new tacit insights through their participation in collaborative networks and their subsequent inter-organisational communications. By exploring the participation of scientists in the ENFSI Digital Evidence working group, we have empirically shown how members willingly help other members through giving advice asked of them, where some form of tacit knowledge is transferred (see Figure 2). A FSL forensic scientist, on joining the ENFSI Digital Evidence collaborative network, built up professional relationships through a series of attendances at its annual conferences and resultant inquiritive emails to members who had been socially targeted. A nascent FSL Digital Evidence service was formed as a direct result of the FSL forensic scientist having received advice, from those targeted members of the ENFSI Digital Evidence collaborative network, in the form of tacit knowledge required to operate successfully the nuances of the dense mobile phone interrogative procedures. From participant observations it was found that the majority of knowledge that was required to be able to set up the FSL's digital evidence service was of a tacit face-to-face nature. A proper functioning digital evidence specialty would not have been set up were it not for the attendance of the FSL forensic scientist for a full week at a laboratory in France [FR (1-4), Figure 3] and a full day at a laboratory in the UK [UK5]. At both laboratories there was extensive tacit knowledge captured through intense one is to one face contact. Likewise tacit knowledge from a highly experienced forensic scientist in the UK [UK 2] allowed robust quality assurance attributes to be added to the laboratory protocols, from face to face meetings at the network conferences [UK2a(way)] and through direct contact from a visit by the UK scientist to the local FSL community [UK2h(ome)]. Figure 2 shows the FSL forensic scientist [FSL a(way)] gaining tacit knowledge from members of the collaborative network [country code(n)]. The FSL forensic scientist [FSL h(ome)] brings back the tacit knowledge to set up a nascent digital evidence service and shares this knowledge locally with two colleagues [FSL 2\&3].

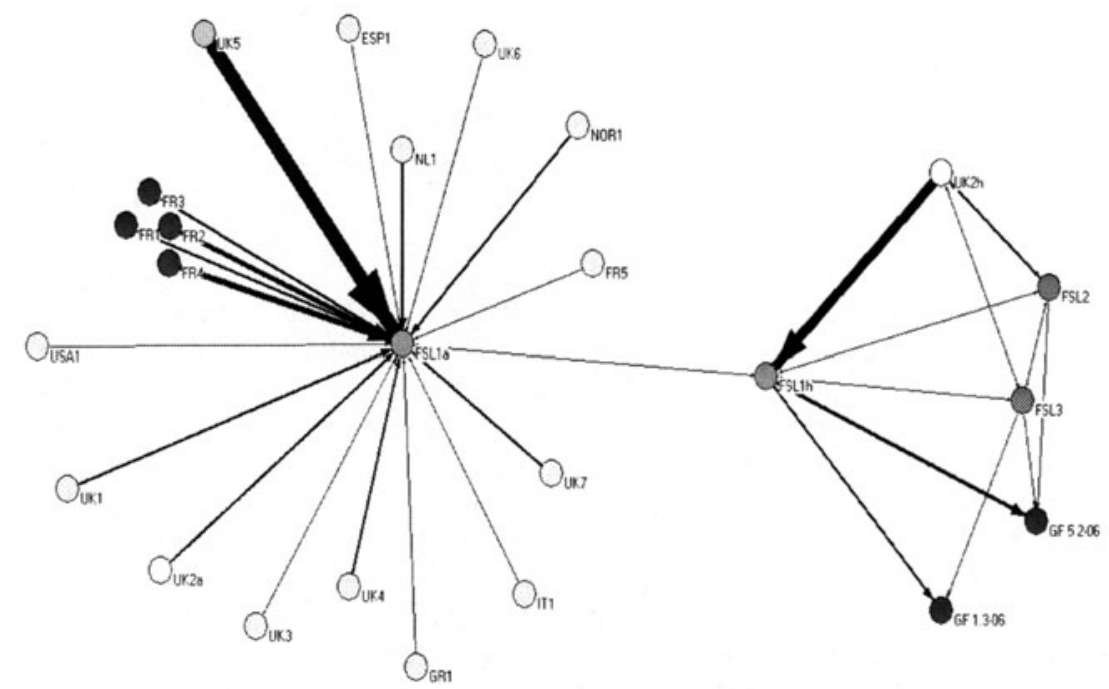

Figure 2. ENFSI Digital Evidence collaborative network [left] - bringing back tacit knowledge to the local FSL nascent digital evidence community [right]. 
The services made available to the police $G($ arda $S$ (iochana)] $1 \& 2$ were discussed with FSL forensic scientists.

In another collaborative network - IABPA, we show how innovations in blood pattern analysis not available in the local community of practice are brought from the IABPA collaborative network back to the FSL Biology community of practice by a senior FSL scientist [c h(ome) \& c a(way)] (Figure 3). We see how four separate innovations from a large wealth of new ideas are chosen to be brought back [blue, green, turquoise, yellow discs]. We capture the interaction of tacit knowledge exchange back at the local community as the new innovations are being brought back. Through participant observation a thorough discussion of one of the four innovations originating from France [Fr 2] was witnessed, where the FSL scientist $c$ presented findings to $d, e$, and $i$ and to the other members of the local community.

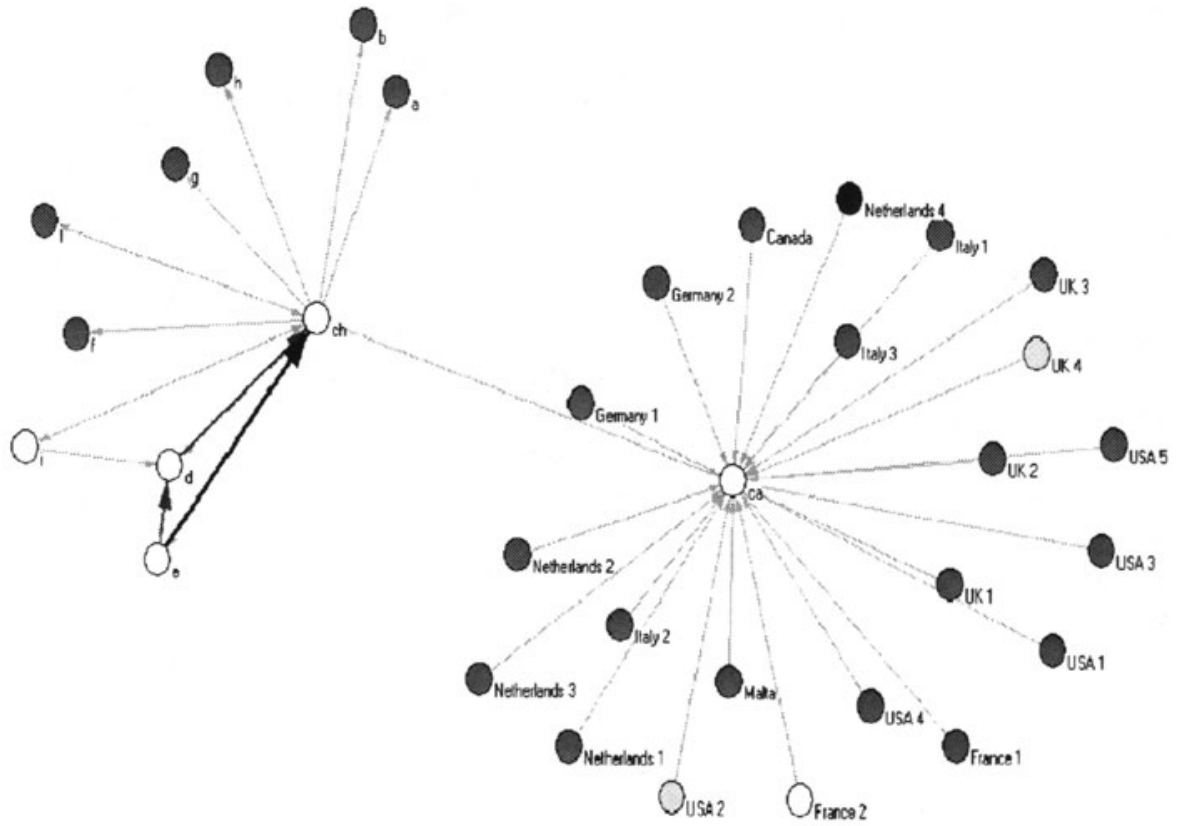

Figure 3. IABPA collaborative network [right] - bringing back tacit knowledge to the local FSL biology community [left].

\subsection{Personal insights of how Tacit Knowledge a major constituent of intra-organisational collaborative communication - inside FSL}

It was found that all the interviewees, who were asked what was the major contributor as to why they would collaborate with colleagues inter-organisationally, mentioned that there was a need to acquire the tacit dimensions of how to proceed within a certain amount of their processes. We discovered why forensic scientists needed to continually communicate and confer with each other. Although we found that FSL forensic scientists were very adept at examining any piece of evidence that added to the bigger picture through interpretation, where they ultimately compiled a report readied for the prosecution service to present to the courts, they still needed a 
localised social acceptance recognising that they carried out the correct procedures. A forensic scientist's need is to collaboratively confer with a fellow forensic scientist who is higher in the pecking order, who has already experienced through their own years of practice, the answer to the question that they seek. One explains:

... When I have a conflict in my head I suppose is the main thing when I think, Oh it could be this, and that might be the easy one, and that might be the road I would be tempted to go down, but maybe it would be something else, so I really should get somebody else's opinion on it.

or more directly, another admits:

... I go out and ask people when I'm unsure myself.

The real need of a forensic scientist is that they are comfortable with their decision, in having made the correct judgement or having expressed fairly an opinion, because their subjectivity will only be tested in the loneliness of the witness box, within the courtroom. A scientist speaks of the journey:

...I think because of the adversarial system in the court you really need to be bouncing your ideas and opinions off somebody else because they are always going to be challenged in the long run by somebody else either by a defence scientist or by a defence barrister so you really need to make sure that your opinions are sound all the time.

The adversarial system frames the way another forensic scientist guards herself:

...I seek advice... if I'm working in an area and a case that I've had to think out of the box and I want it challenged to check its robustness - then I will go - I will actually pick people that I know will be awkward and difficult and I'd go to them and say right this is how I'm thinking, now, I want you to beat it down.

\subsection{The Relational Tacit Dimensions of Inter-Organisational Collaboration - personal opinions from withn FSL to the outside}

Qualitatively we examine more indepth how the tacit knowledge trickles from the outside collaborations back to the local networks. The tacit dimensions of collaboration outside the FSL were captured. In essence, as one forensic scientist expressed the function of such groups when serving on a UK/Ireland collaborative network:

... the Body Fluids Forum is a great way of gaining knowledge and learning about situations other people have been in and how they have dealt with them. Increasingly we are looking outside...

and another expressed their usefulness: 
...I think you get a lot of information from outside, going to meetings and things like that...

and another stated:

... there is a certain amount of knowledge you'll gain by references and literature and by conferences and by networking with other forensic scientists

These personal insights demonstrate how tacit knowledge is brought from the outside back to within the organisation, as is visualised in our network analysis of the IABPA (see Figure 3). The advantage in having been involved in such collaborations is that the forensic scientist feels that they are working on a par with the best practice in Europe, stating:

...now we are as experienced as they are ...

\section{CONCLUSION}

Our empirical research gives a better understanding of tacit knowledge acquisition, how it is formulated in organisations, and how it is passed on to individual knowledge workers. From the point of view of practice it is possible to understand the flow of tacit knowledge into and within organisations. We see that the transfer of tacit knowledge is linked to social relations and the relationships of social actors developed through shared practice.

We can consider tacit knowledge acquisition and application, as a function of participation in collaborative communities of practice (Tschannen-Moran \& NestorBaker 2004), present in the situation (Giroux \& Taylor 2002) within a complex social process (Brown \& Duguid 2001), and in the flow of practice (Duguid 2005). People in sharing a practice, will share know how, or tacit knowledge (Brown \& Duguid 2001). Through qualitative analysis of interviewee comments, we find that tacit knowledge has an implicit richness embedded in the collaborative traffic (Tschannen-Moran \& Nestor-Baker 2004). This is a study of the environment in which tacit knowledge is created and shared within or across organizational boundaries and communities of practice.

Our future research will include more indepth studies of relationships that yield to the lubrication of tacit knowledge flows, with a purpose to inform the organisational management literature of the importance of the interaction of social actors who feel comfortable within collaboratative groups thereby yielding more knowledge exchange.

\section{REFERENCES}

1. Anand, V., Glick, W. H., \& Manz, C. C. 2002, "Thriving on the knowledge of outsiders: Tapping organizational social capital", Academy of Management Executive, vol. 16, no. 1, pp. 87-101. 
2. Batagclj, V. \& Mrvar, A. Pajck 1.03. 2005. http://vlado.fmf.uni-lj.si/pub/nctworks/pajck/default.htm. Ref Typc: Computcr Program

3. Borgatti, S. P., Everctt, M. G., \& Frecman, L. C. 2002, UCINET 6.0 for Windows: Softwarc for Social Network Analysis. Analytic Technologics., Harvard, MA.

4. Borgatti, S. P. \& Cross, R. 2003, "A Relational Vicw of Information Secking and Learning in Social Networks", Management Science, vol. 49, no. 4, pp. 432-445.

5. Bos, N., Zimmerman, A., Olson, J., Ycw, J., Yerkic, J., Dahl, E., \& Olson, G. 2007, "From shared databases to communitics of practice: A taxonomy of collaboratorics - art. no. 16", Journal of Computer-Mediated Communication, vol. 12, no. 2, p. 16.

6. Bouty, 1. 2000, "Interpersonal and interaction influences on informal resource exchanges between R\&D rescarchers across organizational boundaries", Academy of Management Journal, vol. 43, no. I, pp. 50-65.

7. Brown, J. S. \& Duguid, P. 2000, The Social Life of Information Harvard Business School Press, Boston.

8. Brown, J. S. \& Duguid, P. 2001, "Knowledge and Organization: A Social-Practice Perspective", Organization Science, vol. 12, no. 2, pp. 198-213.

9. Collins, J. D. \& Hitt, M. A. 2006, "Leveraging tacit knowledge in alliances: The importance of using relational capabilitics to build and leverage relational capital", Journal of Enginecring and Technology Management, vol. 23, no. 3, pp. 147-167.

10. Cross, R., Borgatti, S. P., \& Parker, A. 2002, "Making invisible workvisible: Using social network analysis to support strategic collaboration", California Management Revicw, vol. 44, no. 2, p. 25-+.

11. Doak, S. \& Assimakopoulos, D. 2006, "A Tacit Knowledge perspective on the knowledge dynamics occurring within/beyond communitics of practice in a knowledge intensive environment.", D. Bennet et al., eds., Aston Busincss School, Aston University, Birmingham B4 7ET, United Kingdom and International Association for Management of Technology, University of Miami College of Enginecring, Coral Gables, FL 33124-0623 USA, Birmingham UK, pp. 194-205.

12. Doak, S. \& Assimakopoulos, D. 2007a, "How do forensic scientists learn to become competent in cascwork reporting in practicc: A theoretical and empirical approach", Forensic Science International, vol. 167, no. 2-3, pp. 201-206.

13. Doak, S. \& Assimakopoulos, D. 2007b, "How forensic scientists learn to investigate cases in practice", $R$ and D Management, vol. 37, no. 2, pp. 113-122.

14. Duguid, P. 2005, ““'The art of knowing”: Social and tacit dimensions of knowledge and the limits of the community of practice", Information Socicty, vol. 21, no. 2, pp. 109-118.

15. Giroux, H. \& Taylor, J. R. 2002, "The justification of knowledge: Tracking the translations of quality", Management Learning, vol. 33, no. 4, pp. 497-517.

16. Herbig, B., Bussing, A., \& Ewert, T. 2001, "The role of tacit knowledge in the work context of nursing", J.Adv.Nurs., vol. 34, no. 5, pp. 687-695.

17. Lave, J. \& Wenger, E. 1991, Situated Lcarning: Legitimate peripheral participation Cambridge University Press, New York.

18. Levin, D. Z. \& Cross, R. 2004, "The Strength of Weak Ties You Can Trust: The Mediating Role of Trust in Effective Knowledge Transfer", Management Science, vol. 50, no. 11, pp. 1477-1490.

19. Nahapict, J. \& Ghoshal, S. 1998, "Social capital, intellectual capital, and the organizational advantage", Academy of Management.The Academy of Management Revicw, vol. 23, no. 2, p. 242.

20. Ostcrlund, C. \& Carlilc, P. 2005, "Relations in Practicc: Sorting Through Practice Theorics on Knowledgc Sharing in Complex Organizations", Information Socicty, vol. 21, no. 2, pp. 91-107.

21. Polanyi, M. 1966, The tacit dimension Doubleday, New York.

22. Sofia Percira, C. \& Soares, A. L. 2007, "Improving the quality of collaboration requirements for information management through social networks analysis", International Journal of Information Management, vol. 27, no. 2, pp. 86-103.

23. Swan, J., Scarbrough, H., \& Robertson, M. 2002, "The construction of 'communitics of practice' in the management of innovation", Management Learning, vol. 33, no. 4, pp. 477-496.

24. Tschannen-Moran, M. \& Nestor-Baker, N. 2004, "The Tacit Knowledge of Productive Scholars in Education", Teachers College Record, vol. 106, no. 7, pp. 1484-1511.

25. van Baalen, P., Blocmhof-Ruwaard, J., \& van Heck, E. 2006, "Knowledge Sharing in an Emerging Network of Practice: The Role of a Knowledge Portal", European Management Journal, vol. 23, no. 3, pp. 300-314.

26. Wasko, M. M. \& Faraj, S. 2005, "Why should I sharc? Examining social capital and knowledge contribution in electronic networks of practice", Mis Quarterly, vol. 29, no. 1, pp. 35-57. 